International Journal of Current Advanced Research

ISSN: O: 2319-6475, ISSN: P: 2319 - 6505, Impact Factor: SJIF: 5.995

Available Online at www.journalijcar.org

Volume 6; Issue 4; April 2017; Page No. 3326-3328

DOI: http://dx.doi.org/10.24327/ijcar.2017.3328.0263

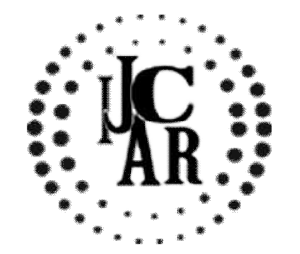

Research Article

\title{
AWARENESS OF JAUNDICE AMONG MOTHERS OF CHILDREN BELOW 10 YEARS OF AGE
}

\author{
Abijeth.B and Brundha.M.P
}

Saveetha Dental College \& Hospitals, Chennai - 600077, Tamil Nadu, India

\begin{tabular}{l}
\hline A R T I C L E I N F O \\
\hline Article History: \\
Received $15^{\text {th }}$ January, 2017 \\
Received in revised form $12^{\text {th }}$ February, 2017 \\
Accepted $22^{\text {nd }}$ March, 2017 \\
Published online $28^{\text {th }}$ April, 2017 \\
\hline
\end{tabular}

Key words:

Jaundice, children, Yellow tinge, Conventional treatment methodology.

\begin{abstract}
A B S T T R A C T
Aim - To assess the Awareness about jaundice among mothers having their children in the age group of below 10 years.

Materials \& Method - Jaundice which is also known as icterus, is a known disease in the society and it may be seen all age groups.A pretested interviewer administered questionnaire will be circulated to 70 mothers of the children below 10 years of age regarding the etiology, signs and symptoms, effects of the disease and preferable treatment methodology.

Results- Overall $57.5 \%$ of the population are aware about the disease Jaundice, Whereas $42.5 \%$ of the population are unaware. The knowledge of the mothers who were aware was adequate in the aspect of identification and signs \& symptoms. Inadequate knowledge among the unaware participants was seen in the aspects of etiology, danger signs and further medical complications of the disease.
\end{abstract}

Conclusion - Though a considerable amount of the population are aware about the disease Jaundice, more awareness is required, as it affects the Indian population most commonly.

Copyright $(2017$ Abijeth.B and Brundha.M.P. This is an open access article distributed under the Creative Commons Attribution License, which permits unrestricted use, distribution, and reproduction in any medium, provided the original work is properly cited.

\section{INTRODUCTION}

Newborn jaundice is the yellowish discoloration of the skin, and mucous membrane occurring in a newborn as a result of increase in the level of serum bilirubin. ${ }^{[1]}$ Physiologic jaundice becomes visible on the second to third day, usually peaking between the second and fourth days at 5 to $6 \mathrm{mg} / \mathrm{dl}$, and decreasing to below $2 \mathrm{mg} / \mathrm{dl}$ between the fifth and seventh days of life. ${ }^{[2]}$ In breastfeeding mothers, breast milk supply may be suboptimal in the first few days, exposing the infants to inadequate fluids and nutrition thus leading to a higher incidence of Neonatal jaundice. ${ }^{[3,4]}$. Neonatal jaundice (NNJ) is a common disorder worldwide affecting 30-70\% of newborn infants. ${ }^{[5-8]}$ It is a frequent cause of hospitalization of babies in the first month of life ${ }^{[9-11]}$ It may be due to either conjugated hyperbilirubinemia or unconjugated hyperbilirubinemia. ${ }^{[8,12,13]}$ The degree of neonatal hyperbilirubinemia in the healthy newborn infant has been shown to depend on many factors including maternal race, maternal disease, gestational age,male sex, instrumental delivery, bruising, previous sibling with the history of neonatal jaundice, weight loss and breast feeding. ${ }^{[14-22]}$. The dangers of elevated levels of bilirubin in the newborn these include cerebral palsy, mental retardation, dental dysplasia, upward gaze paralysis and hearing loss. ${ }^{[1]}$. However, the latter condition occurs much more frequently and also leads to

*Corresponding author: Abijeth.B

Saveetha Dental College \& Hospitals, Chennai - 600077,

Tamil Nadu, India brain damage (kernicterus) in severe circumstances. ${ }^{[8,12,23]}$. Kernicterus is characterized by bilirubin staining of the basal ganglia and involves diffuse neuronal damage. ${ }^{[2]}$ Pregnancy with jaundice is considered as a high risk pregnancy. Viral hepatitis is the most common cause of jaundice in pregnant women. Incidence of hepatitis varies greatly around the world. In developed countries, the incidence is around $0.1 \%$ whereas in developing countries it can range from $3-20 \%$ or higher. There is no difference in the course of the disease in pregnant and non pregnant women in developed countries. However, in developing countries, there is a higher incidence of maternal mortality with fulminant hepatitis. The various maternal complications associated with viral hepatitis are preterm labour, obstetric hemorrhage, fulminant hepatitis, hepatic encephalopathy, renal failure, DIC and death. The various foetal complications are prematurity and intrauterine risk of transmitting the hepatitis infection. ${ }^{[25-27]}$

\section{MATERIALS AND METHOD}

A pretested interviewer administered questionnaire was framed regarding the knowledge about the term " jaundice", Awareness about neonatal jaundice, the viral causative agent, the signs and symptoms and the type of treatment methodology and it was circulated among 70 mothers who have their child in the age group of below 10 years. The 70 participants filled the questionnaire in a proper manner based on their knowledge and experience and the filled 
questionnaires were then statistically analyzed to generate appropriate results.

\section{RESULTS}

About the Neonatal Jaundice, $57 \%$ of the participants children had neonatal jaundice and they were aware about that, whereas $43 \%$ of them have not experienced it and they did not know about it. (Figure 1)

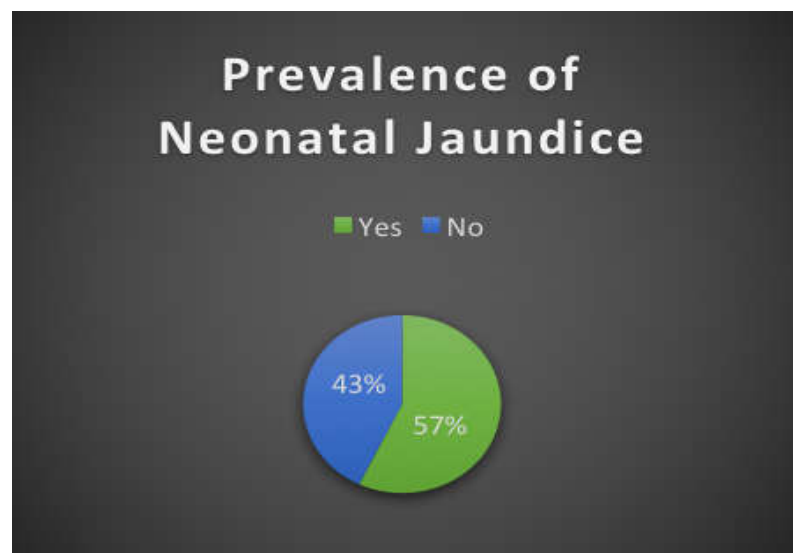

Figure 1

Based on the study, $34 \%$ of the participants knew that Anaemia may lead to Jaundice and remaining $66 \%$ of the participants were unaware.(Figure 2)

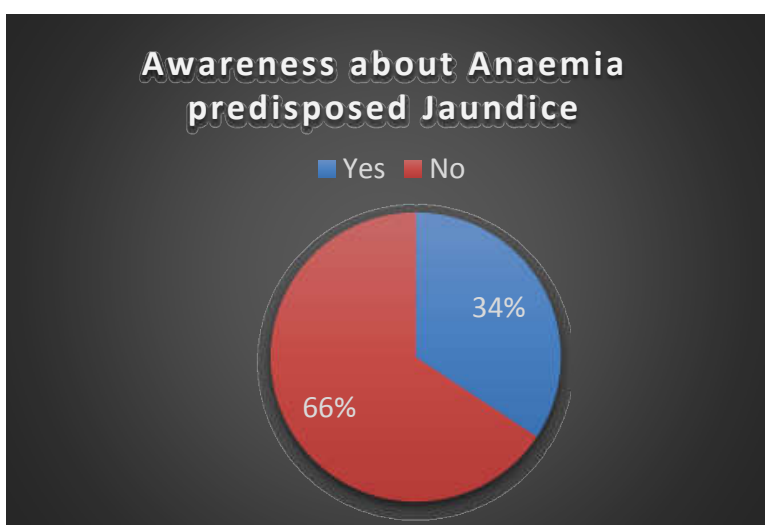

Figure 2

Based on the study, $56 \%$ of the participants were aware of the virus causing jaundice i.e., Hepatitis and $44 \%$ of them dint know about the viral infection.(Figure 3).

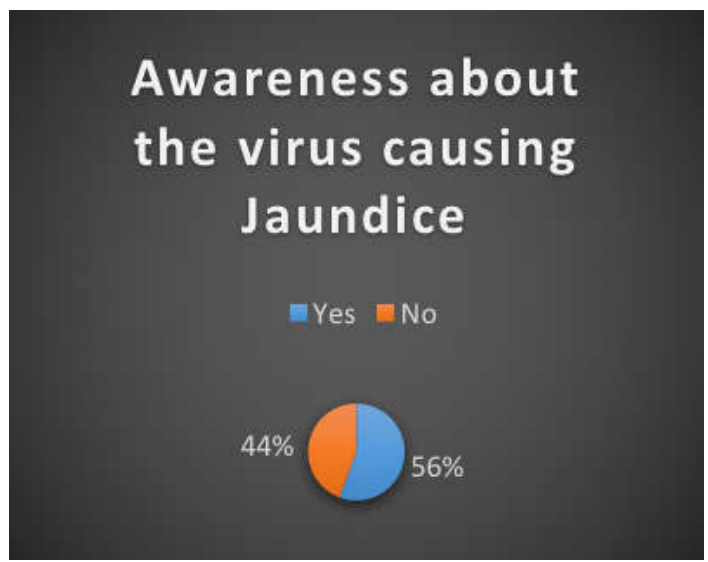

Figure 3
The participants knowledge about the signs and symptoms of jaundice were surveyed. Among which $97 \%$ of the population were able to identify the yellow tinge found over the skin and conjunctiva and $83 \%$ about dark urine, $75 \%$ have observed abdominal pain and $80 \%$ have seen fever and vomiting. (Figure 4)

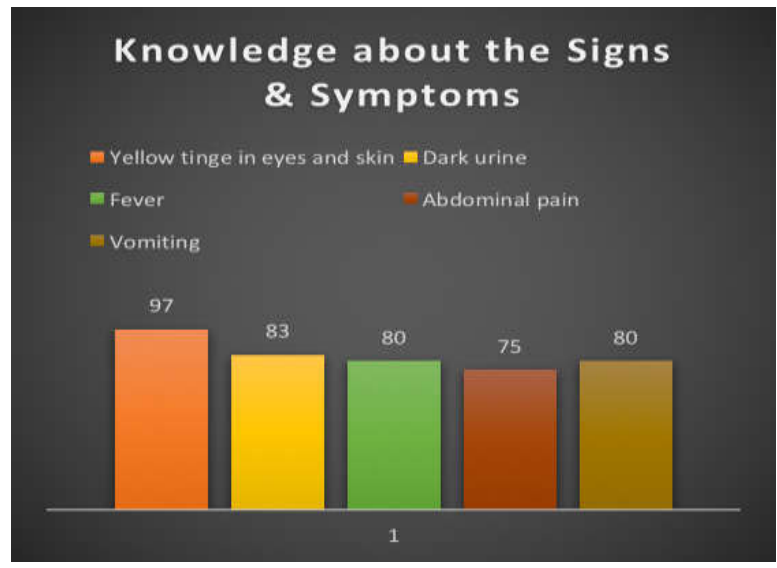

Figure 4

The treatment methodology most commonly preferred was surveyed and based in the result $60 \%$ of the participants prefer conventional home remedies to treat their jaundice affected child and $40 \%$ of them prefer Allopathic treatment methodology. (Figure 5).

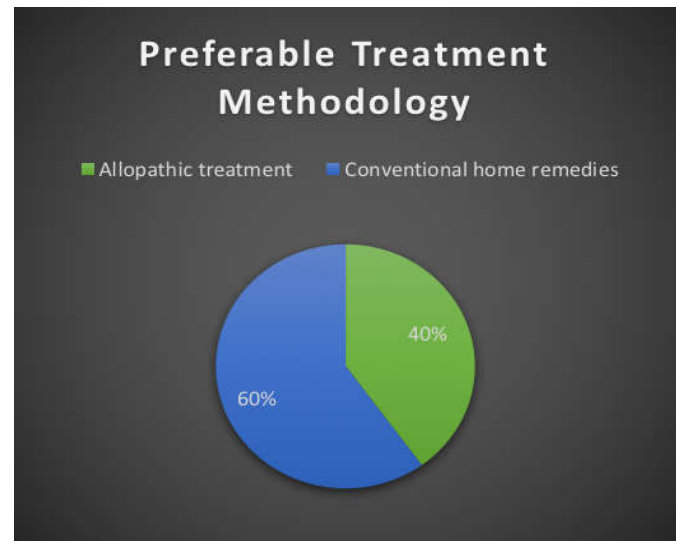

Figure 5

\section{DISCUSSION}

The present study observed that $57.5 \%$ of the total participants were aware of Jaundice. This is probably due to the literacy level observed among them. In the study it was seen that approximately $70 \%$ of mother populations were literate with majority of them having education up to middle level and $30 \%$ of population was illiterate. Similar literacy status was observed by Ashok et al ${ }^{[28]}$ in 2006 after evaluating 8130 women attending antenatal clinics. It was important to note that a small proportion of the mothers had their source of information from the mass media, school, or from books. The knowledge of the mothers who were literate was adequate in the aspect of awareness, signs \& symptoms. Inadequate knowledge about the causes, treatment, complications, and danger signs of Jaundice was seen among $42.5 \%$ of the total participated population \& maybe coupled with various misconceptions about the condition that may adversely affect. There is a need therefore to teach pregnant women to be vigilant and watch out for jaundice on a 
daily basis after the birth of their babies. This can be included in an information pamphlet to be given to all antenatal \& postnatal clinic attendees. They must also be told during health talks when they meet up their gynecologist \& their pediatrician.

\section{CONCLUSION}

Overall $57.5 \%$ of the population are aware about the disease Jaundice, Whereas $42.5 \%$ of the population are unaware. More awareness is required about the disease, as it affects the Indian population most commonly. Etiology of the disease may differ but the basic knowledge about the disease should be imparted to everyone in the general public especially to the women in the child bearing age and the mothers.

- Recommending health talks and information pamphlet on Jaundice should be given to all.

- Radio and television commercials can also be used to disseminate information on the condition to the general public so as to increase the depth of knowledge in the community.

- Awareness camps can be conducted in rural schools, so that the knowledge about the disease will be imparted successfully to the newer generation entering the society.

\section{References}

1. Okposio MM, Adebanjo EO. Evaluation of knowledge and perception of newborn jaundice among parturient mothers in a secondary health care centre in the Niger Delta region of Nigeria. Bangladesh Journal of Medical Science Vol. 13 No. 03 July'14 292-97

2. Behrman RE, Kliegman RM, Jenson HB, editors. Nelson Textbook of Pediatrics. 16th ed. Philadelphia: Saunders; 2005. p. 511-28.

3. Blackmon LR, Fanaroff AA, Raju NK. National Institute of Child Health and Human Development. Research on prevention of bilirubin induced brain Injury and kernicterus: National Institute of Child Health and Human development conference executive summary 2003. Pediatrics 2004; 114:229-33.

4. BA Egube, AN Ofili, AR Isara, JU Onakewhor.Neonatal jaundice and its management: Knowledge, attitude, and practice among expectant mothers attending antenatal clinic at University of Benin Teaching Hospital, Benin City, Nigeria, Nigerian Journal of Clinical Practice;AprJun 2013;Vol 16; Issue 2: 188-194

5. Juretschke LJ. Kernicterus: still a concern. Neonatal Netw 2005; 17(2): 167-9.

6. Mohammadzadeh A, Farhat AS, Iranpour R. Effect of clofibrate in jaundiced term newborns. Indian J Paediatr 2005:72:123-6.

7. Janjidamai W, Tansantiwong T. Accuracy of transcutaneous bilirubinometer estimates using Bilicheck in Thai neonates. J Med AssicThai 2005; 88(2):187-90.

8. Newman TB, Maisels MS. Kernicterus in otherwise healthy, breastfed term newborns. Pediatr 1995; 96:730-3.

9. Kilic S, Texcan S, Tascilar E et al. Morbidity and mortality characteristics of infants hospitalized in the Pediatrics Department of the largest Turkish military hospital in 2001. Mil Med 2005; 170(1): 4851.
10. Escobar GJ, Greene JD, Hulac P et al. Rehospitalization after birth hospitalization: patterns among infants of all gestations. Arch Dis Child 2005; 90(2):125-31.

11. Owa JA, Oshinaike AI. Neonatal morbidity and mortality in Nigeria. Indian JPediatr 1998; 65(3):441-9.

12. Hansen TW. Treatment of neonatal jaundice. Tidsskr Nor Laegeforen 2005; 125(5):594-8.

13. Olusoga B. Ogunfowora1, MBBS, FWACP; Peter O. Adefuye2, MBBS.What Do Expectant Mothers Know about Neonatal Jaundice?. International Electronic Journal of Health Education, 2006; 9:134-140

14. Maisels MJ, Gifford K, Antle CE, Leib GR. Jaundice in the healthy newborn infant: a new approach to an old problem. Pediatrics 1988; 81:505-11.

15. Linn S, Schoenbaum SC, Monson RR, Rosner B, Stubblefield PG, Ryan KJ. Epidemiology of neonatal hyperbilirubinemia. Pediatrics 1985; 75:770-4.

16. Osborn LM, Reiff MI, Bolus R. Jaundice in the full-term neonate. Pediatrics 1984;73:520-5

17. Drew JH, Barrie J, Horacek I, Kitchen WH. Factors influencing Jaundice in immigrant Greek infants. Arch Dis Child 1978;53:49-52

18. Wood B, Culley P, Roginski C, Powell J, Waterhouse J. Factors affecting neonatal jaundice. Arch Dis Child 1979;54:111-5

19. Cambell N, Harvey D, Norman AP. Increased frequency of neonatal jaundice in maternity hospital. $\mathrm{Br} \mathrm{Med} J$ 1975;2:548-52

20. Friedman L, Lewis PJ, Clifton P, Bulpitt CJ. Factors influencing the incidence of neonatal jaundice. $\mathrm{Br}$ Med $\mathrm{J}$ 1978;1:1235-7

21. Jeffries MJ. A multifactorial survey on neonatal jaundice. Br Med J Obstet Gynecol 1977;84:452-5

22. Rena Gale, Daniel S, Siedman, ShaulDollberg and David $\mathrm{K}$ Stevenson. Epidemiology of neonatal jaundice in the Jerusalem population. J pediatrGastroenterolnutr, Vol 10, No $1 ; 1990$

23. Bhutani VK, Johnson LH. Newborn jaundice and kernicterus-health and societal perspectives. Indian JPediatr 2003; 70(5):407-16.

24. Dennery PA, Seidman DS, Stevenson DK, Neonatal hyperbilirubinaemia. New Engl J Med 2001; 344:581-90.

25. Kumar RM, Uduman S, Rana S, Kochiyil JK, Usmani A, Thomas L. Sero-prevalence and mother-to-infant transmission of hepatitis $\mathrm{E}$ virus among pregnant women in the United Arab Emirates. Eur J ObstetGynecolReprod Biol. 2001; 100:9-15.

26. Medhat A, Sharkawy MM, Shaaban MM, Makhlouf MM, Ghaneima SE. Acute viral hepatitis in pregnancy. Int $J$ Gynaecol Obstet. 1993; 40:25-31.

27. Suruchi Shukla*, Geeta Mehta, ManojJais, Abha Singh. A Prospective Study on Acute Viral Hepatitis in Pregnancy; Seroprevalence, and Fetomaternal Outcome of 100 cases. J Biosci Tech, Vol 2 (3),2011,279-286

28. Kumar A, K. Sharma A, Gupta RK, Kar P, ChakravartiA. Prevalence \& risk factors for hepatitis C virus among pregnant Women. Indian J Med Res. Sep 2007; 126: 211 215 